\title{
GRAMMATICAL COMPARISON OF NOUN; INDONESIAN AND JAPANESE LANGUAGES
}

\author{
Diana Kartika ${ }^{*}$, Eky Erlanda Edel ${ }^{2}$, Atmazaki $^{3}$ \\ ${ }^{1 *}$ Department of Japanese Literature, Faculty of Humanities, Bung Hatta University, Indonesia, ${ }^{2}$ Department of English for \\ Business and Professional Communication, Politeknik Negeri Jakarta, Indonesia, ${ }^{3}$ Universitas Negeri Padang, Indonesia. \\ Email: ${ }^{* 1}$ dianakartika@ bunghatta.ac.id, ${ }^{2}$ ekyedel@ gmail.com, ${ }^{3}$ atmazaki@fbs.unp.ac.id
} Article History: Received on $30^{\text {th }}$ August 2019, Revised on $30^{\text {th }}$ September 2019, Published on $14^{\text {th }}$ October 2019

\begin{abstract}
Purpose of the study: The purpose of the study was to analyze the grammatical function of the noun of Japanese and Indonesian language and diversification of Noun and the system of inflectional of two language

Methodology: The methodology of the study was qualitative that focused on library research. In this case, the author conducted constructive analysis to analyze the similarities and differences of the languages in terms of form and function by text-book based on Indonesia and the Japanese Language. The text-book based constructive analysis of library research was chosen to be able to evaluate and renovate the text-book used by language students; Indonesian and Japanese so that their understanding of language comparison and contrast of those languages would be better in the future. Additionally, the lingual contrastive theory was also applicated to establish the term of comparison of the noun of Indonesian and Japanese. From the analysis of the data, it found that the diversity of Noun Forms of Japanese as the subject or the object is classified by particles such as WA,O. A different variation is reflected in the form of the noun of Indonesian where it is not followed with the word of the object.
\end{abstract}

Main Findings: This study also found that the equality form of Noun between Indonesian and Japanese in terms of the function of the subject and the object that refers to the name of people, place, etc.

Applications of this study: The implication of the study is applicated with the process of language acquisition of Japanese as the foreign language of Indonesian students, especially in evaluating and renovating the text-book used by students.

Keywords: Grammatical Comparision, Noun, Constructive Analysis, Indonesian, and Japanese language.

\section{INTRODUCTION}

Diversity of languages is the main object of applied linguistic. According to (H. G. Tarigan, 1990.)Japanese is very much different in the aspect of alphabetic and grammatical composition with the Indonesian Language, for instance, Japanese grammar has a pattern: subject $(\mathrm{S})$, object $(\mathrm{O})$, and predicate $(\mathrm{P})$ that abbreviated with S.O.P. Meanwhile, Indonesian grammar has a pattern: subject (S), predicate (P), and object (O) that abbreviated with S.P.O (Alwi, Hasan, 2003). Distinctly is also reflected in the different functions, alphabetic formulation, and its meaning are also specifically in terms of the features of each language. In addition, the form of verb of Japanese language is transformed, but in Indonesian language is not, because the function of the verb of Indonesian sentence is not influenced of any contextual of the information.

Noun as the part of Subject and the Object of the sentence two languages (Japanese and Indonesian) has a distinct grammatical arrangement. According to (Keraf, 1997) in Indonesian grammatical composition, Noun can not stand alone; it needs to be provided with additional adverb of adjective that subordinated with conjunction words such as "Yang" such as "Ibu yang baik" (A good mother). "Ibu" as the Noun is not clarified well yet if it is not completed with adjective complement such as “.... yang baik”. In addition, affix words in Indonesia do not have any meaning; it just provides specific affirmation to the root words such as "ke-an" in the words "kebudayaan" where "budaya" as the root and it is added with more specific affix (prefix "ke-" dan suffix "-an"), but it is still as a noun in Indonesian. On the other hand, the Japanese noun (Meishi) has different classification where every noun has its own words such as animal, place, time signal, abstract noun and so forth (Saputra, 2016). According to(Sudjianto., 2010) says that Meishi of Japanese is divided into 5 (five) group, namely Koуиu, Meishi, Daimeishi, Fursuumeishi, Keishikimeishi, and Sushi where each of them has the vocabulary which is classified by its function.

Based on the grand tour explanation above, it can be assumed that the diversity of grammatical aspects of two languages gives great difficulties for the participant of language acquisition. Those difficulties can be burdened on a group of Japanese language learners where the target language is the foreign language. Japanese as the foreign language is not only informal communication tool but also has significant distinction in the form than Indonesian. Therefore, this research was going to explore furthermore related to the diversity and similar noun words of two languages between Indonesia and Japanese. Basic issues of the study were formulated into 3 research questions; 1) How did the form of a noun in the Indonesia language? 2) How did the form of a noun in the Japanese language? 3) What were the differences and similarities between the forms of the noun in Indonesian and Japanese languages?

\section{METHODOLOGY}

The methodology of the study was qualitative that focused on library research. In this case, the author conducted consturc- 
-ive analysis to analyze the similarities and differences of the languages in terms of form and function by text-book based on Indonesia and the Japanese Language. The text-book based constructive analysis of library research was chosen to be able to evaluate and renovate the text-book used by language students; Indonesian and Japanese, so that their understanding of language comparison and contrast of those languages would be better in the future (Kothari, 2004). The qualitative approach is obtained as the basic framework of though of the research (Sutrisno, 1993). In analyzing the sources of the data, this research applies two languages comparison an implication of the research as well as a theoretical perspective and it is also significant for the study of individual language and the understanding of different languages (Grabe, W., and Kaplan, 2014). Since the research was to observe two language comparative studies, constructive analysis was required to do deep investigation and examination of the form and cross-linguistic analysis. (Tyler, 2012) states that contrastive linguistics can refine the study of form and cross-linguistic analysis. Through contrastive linguistics, the objective of the research is intended to investigate analysis the form and each of different aspects of the languages. The result of analysis concern with the similarity and differences of two languages; as well in order to find the similarities and differences between the two languages in terms of form and function. According to ( $\underline{H}$. G. dan D. T. Tarigan, 2009) the contrastive analysis has five steps: 1) collecting data, in this case, two languages were analyzed, 2) identifying and classifying the differences and similarities between the two languages, 3) analyzing the errors and learning difficulties, 4) evaluating the errors, and 5) preparing the teaching materials to analyze the object of the study; that is the nouns contains in Indonesian and Japanese sentences. It can be stated that the principle of the research described and analysed the nouns both Japanese and Indonesian languages

\section{DISCUSSION / ANALYSIS}

\section{The nouns in the Bahasa (Indonesian Language)}

The noun is also called as "nominal", such as an animal, an astrology, a deed, a king, a kingdom, a chess, and a chord, or it is the word generally places as a subject, an object, or a complement function in a clause, main function, in the word limitation, in a phrase, and the expression of 'unity of life', 'lifeless unity,' concrete 'or' abstract' things (Arifin, 2007). The nouns may be depicted its functions in clauses, sentences or phrases. The noun is commonly occupied by a noun with its function of the subject $(\mathrm{P})$ and the function of the object $(\mathrm{O})$. In this research, the researcher categorizes nouns for some types.

\section{Noun and Its Functions}

First of all is a noun with its functions in sentences that can be seen as the following (Badudu, 1992); First, noun as subject. The words that have functioned as the subjects are italic; (a) Pemain sepak bolaitusudahkelelahan. (Eng: The soccer player has been exhausted), b) Tebakannyabenar.(Eng: His/Her guess is correct), Ibunyasudahbekerjaseharian. (His/Her mother has worked all day)-nyain Indonesian acts like possessive pronoun explaining something belongs to the third singular person (His/Her). In general, the subject always places in front of a sentence, even though it is sometimes preceded by an adverb, for example, a) Tiba-tibaAdikjatuhkekali.(Eng: Suddenly my brother felt down to the ditch). b) Pada suatu hari seekor harimau memangsa Sang Kancil.(Eng: One day, the tiger preyed the antelope), c) Barangkali tebakannya benar.(Eng: Perhaps his/her guess was correct.). Second, noun as object. The words that have functioned as the objects are italic. a) Pemain sepak bolaitusudahkelelahan (Eng: the football player has felt exhausted), b) Tebakannya benar (Eng:His guess is correct), c) Ibunyasudahbekerjaseharian (Eng: His mother has worked all day). The following sentences are also examples of a noun as an object. The words that have the function as the object are italic; a) Maria menulispuisi. (Eng: Maria writes a poem), b) Sang Kancil mengelabuiSang Buaya. (Eng: The antelope deceived the crocodile), c) Mahasiswa mengibarkanSang Saka. (Eng: The college student hoisted Sang Sakal). The noun as an object which is occupied before a certain verb is called transitive, such as make, throw, do, sing, etc.

Third, noun as complement. The nouns in "intransitive" sentences do not occupy as the function of the object but the function as a compliment, such as meeting, name, constitute, make, and expose. In the following examples, the words as a complement are italics; a) Perusahaan itubergantinama (Eng: The company has renamed), b) Banyak wilayahterkenamusibah (A lot of areas was exposed to disaster), c) Indonesia berlandaskanhukum = (Indonesia is based on the law). Fourth, noun as predicate. In the Indonesian language, the function of the predicate is not only expressed by the verbs but also occupied by the nouns and adjectives. Here are some examples of nouns that are occupied as the function of the predicate.In the following examples, the words serve as the predicate are italics; a) Nama sayaUdin (Eng: My name is Udin), b) Yang diincarIndonesia (Eng: It is being targeted by Indonesia), c) Tempat lahirsayaPadang (My hometown is in Padang). Finally, noun as Independent Clause. The nouns can have functioned as an independent clause. It means that the noun is the core of things and marks the phrase. The words as the independent clause in the sentences below are italics; a) daftarminuman (Eng: TheDrink list), b)surat edaran (Eng: TheCircularLetter), c) hidanganlezat (Eng: Thedelicious food serving).

\section{Noun as Its Forms}

Based on its form, a noun is divided into two groups (Efendi, 2015); first, a noun does not have mark form and does not

\footnotetext{
${ }^{1}$ Sang Saka is the honorable name for Indonesian flag. 
have affixes, such as clouds, earth, leaves, mountains; second, a noun has mark form and is bound by the affixes, such as rules and security. 1) The noun does not have a marked form. The word "Awan" is known as a "noun" because its position is in the sentence, for example, "Awanberarakdilangit",, "Matahari tertutupawan ", "Awan itumenyerupairaksasa". In the first sentence "awan" has had its function as subject (S). In the second sentence, the "awan" has its function as a complement. In the third sentence, the "awan" has its function as the noun "awan' itself because it is followed by the word "itu (Eng: the)" 2) Noun has marked forms such as affixes, and suffixes. Furthermore, there are a number of affixes, if affixed or added by to the basic word, they will create new types of noun. The additional word of affixes are per-, pe-, ke-, -an, ter-, ke-...-an, per-...-an, and pe-...-an. The additional of the prefix of $P e(\mathrm{r})$ - to the base word is in the forming a noun Most nouns of this form (in their meaning) relate to verbs beginning ber- (pedagang- berdagang, petinju - bertinju, pemain-bermain, pelari-berlari, etc ${ }^{6}$ ). Here are some examples for verb as based word; a) Inipesuruhkantor kami (Eng: this is our office's courier), b) Ramang adalahpemain bola. (Eng: Ramang is a football player), c) Serengatadalah mantan pelari $100 \mathrm{~m}$. (Eng: Serengat is a $100 \mathrm{~m}$ former runner).

Then, here are some examples for adjective as based word (Cahyono, 1995); a) Para petinggi di departemen itu sangat memperhatikan karyawannya ${ }^{7}$, b) Hama perusak tanaman padi itu sukar dibasmi ${ }^{8}$, c) Adikku seorang periang ${ }^{9}$. Finally, there are some example for noun as based word; a) Suku-suku itu hidup sebagai peladang berpindah ${ }^{10}$, b) Ayahku seorang petani kecil $^{11}$, c) Beberapa orang petinju Indonesia pernah menjadi juara dunia ${ }^{12}$.

In addition, prefix joins the basic word of some kind of words informing the new noun Generally, the nouns produced in the formation are related (meaning) to the word beginning (Nasional., 2008),..., me-, me-...-kan, me-...-i, for example; penyejuk-menyejukan ${ }^{13}$. First, there are some examples of the verb as based word; a) Stadion Utama menggunakanmesinpemotongrumputyangcanggih ${ }^{14}$. b) Pengurus harian perkumpulan itu berkantordi sebelah kantor Camat $^{15}$, c) Para penanam tebu mengharap panen yang bagus tahun ini ${ }^{16}$. Second, there are some examples for adjective as the based word; a) Pendingin udara tidak boleh menggunakan gas Freon ${ }^{17}$, b) Pemanas air ini menggunakan tenaga panas matahari $^{18}$, c) Campuran penguat semen itu dijual dalam kemasan plastic ${ }^{19}$. Third, there are some examples for noun as based word; a) Profesor Watuseke menjadipengarah seminar ${ }^{20}$, b) Para pengguna barang terlarang perlu mendapat perhatian lebih serius $^{21}$, c) Pemilik hak cipta buku ini Pusat Bahasa ${ }^{22}$

After knowing about prefixes, it would not be completed without discussing about suffixes. The addition of the suffix "-an" in the words of 'atur (Eng: arrange)', 'turun (Eng: decline)', 'buat (Eng: make)', 'pukul (Eng: hit)', 'pilih (Eng: Choose)' become new noun as 'aturan (Eng: arrangement)', 'turunan (Eng: derivative)', 'buatan (Eng: made of)', 'pukulan (Eng: hit)', and 'pilihan (Eng: choice)'. The addition of the suffix '-an' in the base words of 'bulat (Eng: round)', 'lapang (Eng: free area)', 'santun (polite)', 'tegang (tense)', and 'unggul (super)' become the new nouns, respectively, 'bulatan (Eng: roundness)', 'lapangan (field)', 'santunan (politeness)', 'tegangan (tension)', and 'unggulan (superior'. Moreover, the addition of the suffix -an to the basic words of 'jaring (Eng: net)', 'batu (stone)', 'alun (', 'laut (sea)', 'darat (land)' become the new nouns, respectively, 'jaringan (network)', 'batuan (rock)', 'alunan (strain)', 'lautan (ocean)' and 'daratan (island) (Sukini., 2010.).

\footnotetext{
${ }^{2}$ Cloud (in English)

${ }^{3}$ The could is drifting in the sky

${ }^{4}$ The sun is blocked by cloud

${ }^{5}$ The cloud looks like a giant

${ }^{6}$ English: Seller-selling, boxer-boxing, player-playing, runner-running, etc)

${ }^{7}$ The boards of head level department are very concerned about their employees.

${ }^{8}$ The pestsfor rice plant'sdamaging are difficult to be exterminated.

${ }^{9}$ My little brother is cheery person

${ }^{10}$ The tribes live as nomadic cultivators

${ }^{11}$ My father is a minor farmer

${ }^{12}$ Some of Indonesian boxers have ever become the world's champion.

${ }^{13}$ Cooler-cooling

${ }^{14}$ The Main Stadium uses a sophisticated lawn mower.

${ }^{15}$ The daily officers of association have an office near the Subdistrict head's office.

${ }^{16}$ The sugarcane growers expect a good harvest in this year

${ }^{17}$ The air conditioners should not use Freon gas.

${ }^{18}$ This water heater uses solar thermal power.

${ }^{19}$ The mixture of cement boosters is sold in plastic packaging.

${ }^{20}$ Professor Watuseke becomes the director of the seminar.

${ }^{21}$ The users of forbidden goods should be received serious attention

${ }^{22}$ The copyright of this book belongs to the Language Center 
Also, in Indonesian grammar structure, there are nouns that have marked ter-, or it means that the noun has limited amount. Here are the examples below (Efendi, 2015); a) Terdakwa dalam perkara penipuan itu mengaku bersalah ${ }^{23}$, b) Seorang pejabat dijadikan tertuduh dalam perkara penyuapan ${ }^{24}$, c) Para tersangka didampingi lima orang pengacara ${ }^{25}$.

Moreover, apocalypse is an affix applied simultaneously in front of and behind the word base. The phenomenon of the noun "ke-...-an' can be affixed on the same basic words but the words are different (Cahyono, 1995). For example:1) The base word is a verb (a) Keadaan cuaca akhir-akhir ini memerlukan kewaspadaan ${ }^{26}$, b) Kami sedang menunggu kedatangan Pak Camat $^{27}$, c) Kedudukan Ansar dalam organinisasi itu cukup tinggi ${ }^{28}$. 2) The base word is an adjective (a) Keelokan putriitumembuat Markus Antonius mabukkepayang ${ }^{29}$, b) Sesudah kemalasan datanglah kemiskinan ${ }^{30}$, c) Narkoba hanya memberikan kesenangan sesaat ${ }^{31}$. 3) The basic word is a noun (a) Istilah kekerabatan berbeda menurut bahasa penuturnya $^{32}$, b) Anggota keluarga kerajaan termasuk golongan bangsawan ${ }^{33}$. 4) The base word is an adverb (a) Anak-anak itu memperagakan kebolehan mereka masing-masing ${ }^{34}$, b) Ada kemungkinan bahwa subsidi pemerintah akan dikurangi ${ }^{35}$.

The noun can be recognized also through its several words of prefix and suffix. The word 'Para (Indonesian language)' refers to a number of people, place, etc., for example: 'para sahabat (some friends)', 'para santri (some Islamic traditional students)', 'para nelayan (some fishermen)', 'para guru (some teachers)'. The word 'Para” is always followed by a noun which has to mean as human or soul. orexample is also known through several words in front or behind it. For example, 'para' in series 'para sahabat', 'para santri', 'para nelayan', 'para guru'. Word 'para' shows the amount more one. Word 'para' only followed by a noun that hasto mean "human or spirits'. It cannot be followed by the word which symbolizes animal or noun which not symbolize humans or spirits.

If the word is not generally followed by a noun, there will be a confused noun or known as the noun's identifier. Some of the examples are the following; a) His name is Wilson (expected as the stranger person), but he is not a stranger, b) Martina is not a tennis player, c) We need a solution, not collusion. The word numbers of nouns can also be a marker of noun's presence, for example, a) Harga cabaimerahpernahmencapaiduapuluhribu rupiah sekilo ${ }^{36}$, b) Pertemuan itu tidak berhasil membuat satu keputusan pun ${ }^{37}$, c) Waktunya tinggalbeberapamenitlagi ${ }^{38}$.

\section{Noun and Its Meaning}

The classification of nouns based on its meaning is complicated. The class is an open class. It means that the number of nouns can be added simultaneously. Every new finding concerned about the object, product, idea, and place usually has a new word that symbolizes the word itself (Efendi, 2015). In general, based on its realm of unity, the noun can be divided into two groups, namely: the animate noun and the lifeless noun. Moreover, based on its sensation, the noun can be divided into concrete and abstract nouns. The concrete noun can be viewed by its real case, i.e., house, river, the moon, rose, etc, meanwhile the abstract noun cannot be viewed by its real case (abstract), i.e., opinion, desire, satisfaction, love, etc.

\section{The Nouns in the Japanese Language}

The noun is the word class of all things and everything has its own name (Saputra, 2016). (Tanimori, 2012) states that a noun refers to people, things, and concepts, it can be placed in the subject or object position of a sentence or can be followed by articles, for example; Watashi, Yamamoto, Neko, Oosaka, Toire, Ai, Houhou. (Tanimori, 2012) defines a noun in Japanese can be fully sentence embedded and not only always followed by the complimentary words, such as verbs, adjectives, captions, and particles, but also followed by the nouns in positive, negative and interrogative form sentences that can be seen as follow; 1) Futshuu Meishi is a common noun such as goods, events, etc. the examples in the Japanese language. : Boushi (hat), Yama (mountain), Jitensha (bike), Matsuri (festival), etc, 2) Koyuu Meishi is a proper noun, such as the name of person, place, etc. For example Yamaha san (Mr.Yamada), Furansu (France), Asahi (name of newspaper), etc. For example; a) Watashi wa Yamada desu. Kochira wa Tanaka san desu, b) Shanhai to Nyunyoku ni ikimasu, 3)

\footnotetext{
${ }^{23}$ The defendant in the fraud case is pleaded guilty.

${ }^{24} \mathrm{~A}$ government officer was made a defendant in a corruption issue.

${ }^{25}$ The suspects were accompanied by five lawyers.

${ }^{26}$ The current weather should be considered carefully

${ }^{27}$ We are waiting for the Head of Sub-district.

${ }^{28}$ Anwar's position in its organization is on top level.

${ }^{29}$ The sweetness of a girl is invited Markus Antonius drunk in love.

${ }^{30}$ If you are laziness, you will be poor

${ }^{31}$ The drugs is a sweat love in a moment

${ }^{32}$ The definition of kinship is varied based the speaker's language.

${ }^{33}$ The members of royal family belong to noble.

${ }^{34}$ The children demonstrate their individual permissibility.

${ }^{35}$ Perhaps the government subsidies will be reduced.

${ }^{36}$ The price of red chili has ever reached IDR 20.000,-/Kilo.

${ }^{37}$ This meeting has not concluded the final agreement at all.

${ }^{38}$ The time has left a few minute.
} 
Keishiki Meishi is an abstract noun. For example: koto, mono, hazu,hodo, wake, bakari, mama, kurai, etc, 4) Suushi is a collective noun. Example: Hachi (eight), Hitotsu (one fruit), Sannin (three), Gomai (five pieces), Ichiban (number one), Rokudai (six motorized objects), etc, 5) Daimeishi is a noun as a pronoun. For example: Watashi (me), Kanojo (he, she), Kore (this), Sochira (that), etc. For example; a) Kono nekowa kawaii desu ne, b) Gakusei ga futari kimashita, c) Soto o sokoshi kudasai.

\section{Nouns Derived from the Verb Form}

Some verbs refer to a noun. For example, the verb 'hajimeru' becomes 'hajime', 'nomi-sugiru' becomes 'nomi-sugi' that has a function as a noun, for example; a) Iki wa basu de kaeri wa takushi desu, b) umare wa doko desu ka, c) Tasuke wa irimasen (Breiler. Everette F., 1993).

\section{Nouns Derived of the Adjectives}

Some adjectives which are followed by the adjective '-sa' or '- $m i$ ' can be nouns(Masuoka, 1992). Here are some examples of changing an adjective into a noun.

\begin{tabular}{c} 
Adjective \\
\hline$a k a i$ \\
fukai \\
shiroi \\
takai \\
tanoshii
\end{tabular}

$$
\begin{gathered}
\text { Noun } \\
\text { aka } \\
\text { fukasa } \\
\text { shiro } \\
\text { takasa } \\
\text { tanoshimi }
\end{gathered}
$$

\section{Positive Sentence}

Positive sentences are divided into two groups, namely present positive and past positive. The examples of present positive sentences (+) are; a) Watasiwa wa Mira desu, b) Joko-san wa gakusei desu, c) Asoko wa uketsuke desu. Moreover, the examples of past positive sentences (+) are; a) Watashi wa koukousei deshita, b) Sengetsu wa natsuyasumi deshita, c) Asoko wa uketsuke deshita (Saputra, 2016).

\section{Negative sentence}

Negative sentences are divided into two groups, namely present negative and past negative. The examples of present negative sentences (-) are; a) Watashi wa Mira dewa arimasen, b) Joko- san wa gakusei ja arimasen, c) Asoko wa uketsuke dewa arimasen. In addition, the examples of past negative sentences (-) are as follows; a) Watashi wa koukousei dewa arimasen deshita, b) Sengetsu wa natsuyasumi ja arimasen deshita, c) Asoko wa uketsuke dewa arimasen deshita (Saputra, 2016).

\section{Interrogative Sentence}

Interrogative sentences are divided into two groups: present interrogative and past interrogative. The examples of present interrogative sentences (+) are; a) Anata wa Mira-san desuka? b) Joko-san wa gakusei desuka?, c) Asoko wa uketsuke desuka? Afterward, the examples of past interrogative sentences (-); a) Anata wa koukousei deshitaka?, b) Sengetsu wa natsuyasumi deshitaka?, c) Asoko wa uketsuke deshitaka? (Saputra, 2016).

\section{Comparison of Nouns in Indonesian and Japanese languages}

In Japanese, the verb is divided into four groups (Kartika, 2017): 1) daimeishi, 2) futsuumeishi, 3) keishikimeishi, 4) koyuu meishi, 5) and suushi. Koyuu meishi is a noun which its name or place is always followed by '-san' or '-sama'. The element of a noun in Japanese language (subject, object) is determined by particles such as ' $W A$ ', ' $O$ ', etc. Meanwhile, the element of the noun Indonesian language is not the element of the noun in Indonesian is determined by the word order. The sentence pattern in Japanese grammar is 'SPO' meanwhile in Indonesian grammar is 'SOP'. The similarities between I Indonesian and Japanese nouns are both embedded occupied by the functions of subject and object which refer to the names of people, places, etc. The Indonesian and Japanese nouns can be fully sentence embedded and are always followed by complimentary words, such as verbs, adjectives, captions, and particles (Kusdiyana, 2002).

\section{CONCLUSION}

Based on the contrastive analysis between the Japanese nouns and Indonesian nouns above, it can be concluded as follow;

1. the Indonesian nouns or premises nouns such as 'perbintangan'39, 'amal' ${ }^{40}$, ' $\operatorname{amalan}^{41}$, ' $\operatorname{raja}^{42}$, ' $\mathrm{kerajaan}^{43}$, 'catur ${ }^{44}$, and 'pecaturan ${ }^{45}$, or the words that generally are embedded the functions of the subject, the object, or the

\footnotetext{
${ }^{39}$ horoscope

${ }^{40}$ deed

${ }^{41}$ Good deed

${ }^{4}$ king

${ }^{43}$ kingdom 
complement in the clause, the main function, the periphery, or the axis in the phrase, the denoting the form, the marked form -an, ke-...-an, per-...-an, and expressing the meaning of 'unity of life', 'lifeless unity, 'Concrete' or 'abstract'.

2. Meanwhile While in Japanese nouns refer to the people, things, and concept, and can be placed in the subject or object position of a sentence or can be followed by the particles.

3. The Indonesian grammar and Japanese grammar are different, i.e. Indonesian grammar is SPO, and meanwhile, Japanese pattern is SOP.

4. The nouns in Indonesian language are divided into 2 groups; 1) the noun and its function is a noun which mentions the function of each of the words, such as S (subject), P (predicate), O (object), and Pel. (Complementary), 2) the noun and its form is the noun which has the unmarked function of the noun itself. The noun element in Indonesian is determined by the word order in the sentence.

5. The verbs in the Japanese language are divided into 5 groups: 1) daimeishi, 2) futsuumeishi, 3) keishikimeishi, 4) koyuu meishi, 5) and suushi. The element of noun in Japanese language (subject, object) is determined by particles such as 'wa', 'o', etc., the meanwhile Indonesian language is not.

6. The similarities between Indonesian and Japanese nouns are both embedded occupied by the functions of subject and object which refer to the names of people, places, etc. The Indonesian and Japanese nouns can be fully sentence embedded and are always followed by complimentary words, such as verbs, adjectives, captions, and particles

\section{ADVANCING STUDY}

The author believes that this research needs to be improved by some other researches. Knowing the fact that some students in Indonesia face problems in literateness (reading enthusiasm), observing and providing the students with proper textbook in learning the language of Japanese and Indonesian based on their needs would make it easier for interactive classrooms.

\section{ACKNOWLEDGMENT}

I would like to thank all those who have helped in the completion of this article to be more perfect.

\section{REFERENCES}

1. Alwi, Hasan, et. a. (2003). Tata Bahasa Baku Bahasa Indonesia. Jakarta: Balai Pustaka.

2. Arifin, Z. dan J. (2007). Morfolohi Bentuk, Makna dan Fungsi. Jakarta: PT. Grasindo.

3. Badudu, J. S. (1992). Cakrawala Bahasa Indonesia II. Jakarta: Gramedia Pustaka Utama.

4. Breiler. Everette F. (1993). Basic Japanesse Grammar. Tokyo: Tutle Publishing.

5. Cahyono, B. Y. (1995). Kristal- Kristal Ilmu Bahasa. Surabaya: Airlangga University Press.

6. Efendi, dkk. (2015). Tata Bahasa Dasar Bahasa Indonesia. Bandung.: Remaja Rosdakarya.

7. Grabe, W., and Kaplan, R. B. (2014). Theory and Practice of Writing: An Applied Linguistics Perspective. New York: Routledge. https://doi.org/10.4324/9781315835853

8. Kartika, D. (2017). Perbandingan Verbatransitif Dan Intransitifbahasa Indonesia Dan Bahasajepang: Tinjauan Analisis Kontrastif. Jurnal KATA, 1(1), 45. https://doi.org/10.22216/jk.v1i1.1721

9. Keraf, G. (1997). Komposisi: Sebuah Pengantar Kemahiran Bahasa. Ende, Flores: Penerbit Nusa Indah.

10. Kothari, C. R. (2004). Research Methodology Methods and Techniques. Second Revised Edition. New Delhi: New Age International Publishers.

11. Kusdiyana, E. (2002). Kontrastif antara Bahasa Jepang dengan Bahasa Indonesia Ditinjau dari Segi Preposisi. Jurnal USU, 16.

12. Masuoka, T. (1992). Kiso Nihongo Bunpou- Kaiteiban. Kuroshio.

13. Nasional., D. P. (2008). Kamus Besar Bahasa Indonesia. Jakarta: PT. Gramedia Pustaka Utama.

14. Saputra, A. dan W. (2016). Jago Kuasai Bahasa Jepang. Yogyakarta: Pustaka Baru Press.

15. Sudjianto. (2010). Metode Pembelajaran Bahasa Jepang. Bekasi.: Kesaint Blanc.

16. Sukini. (2010). Sintaksis; Sebuah Panduan Praktis. Surakarta: Yuma Pustaka.

17. Sutrisno, H. (1993). Research Methodology. Yogyakarta: Andi.

18. Tanimori, M. (2012). Essential Japanesse Grammar. Tokyo: Tutle Publishing.

19. Tarigan, H. G. (1990). Pengajaran Pragmatik. Bandung.: Angkasa.

20. Tarigan, H. G. dan D. T. (2009). Telaah Buku Text Bahasa Indonesia. Bandung.: Angkasa.

21. Tyler, A. (2012). Cognitive Linguistics and Second Language Learning: Theoretical Basics and Experimental Evidence. New York: Routledge. https://doi.org/10.4324/9780203876039

\footnotetext{
${ }^{44}$ chess

${ }^{45}$ Chessing 